\title{
KINERJA GURU SERTIFIKASI PAI MADRASAH ALIYAH SEBAGAI GURU PROFESIONAL DI KABUPATEN PIDIE
}

\author{
Sulaiman \\ Program Studi Pendidikan Fisika \\ Fakultas Keguruan dan Ilmu Pendidikan Universitas Jabal Ghafur
}

\begin{abstract}
ABSTRAK
Penelitian ini dilatar belakangi dengan kondisi objektif Madrasah Aliyah Negeri (MAN) di Kabupaten Pidie.Adapun permasalahan dalam penelitian ini adalah bagaimana kinerja guru sertifikasi PAI lulusan portofolio dan sertifikasi lulusan pelatihan serta perbedaan dan persamaan keduanya pada MAN di kabupaten Pidie.Tujuan yang ingin dicapai dalam penelitian ini untuk melihat kinerja guru sertifikasi PAI lulusan portofolio dan lulusan pelatihan serta persamaan dan perbedaan antara keduanya.Metode yang digunakan dalam penelitian ini adalah metode deskriptif kualitatif, dimana penulis mendeskripsikan kinerja guru sertifikasi PAI pada MAN di Kabupaten Pidie sebagai guru profesional. Responden penelitian adalah guru sertifikasi PAI lulusan pelatihan dari MAN Beureunuen 3 org, MAN Keumbang Tanjung 3 orang, MAN Tangse 1 orang, MAN Kota Bakti 4 orang, MAN Delima 1 orang dan MAN Sigli sebanyak 4 orang. Kemudian responden guru lulusan portofolio terdiri dari MAN Sigli 2 orang, MAN Kota Bakti 1 orang, MAN Beureuneun 1 orang dan 1 orang dari MAN Delima yang ada di Kabupaten Pidie dengan teknik dokumentasi, observasi dan wawancara dengan guru. Analisis data dilakukan dengan cara analisis domain dan analisis taksonomi. Hasil penelitiannya menunjukkan bahwa kinerja guru sertifikasi pendidikan agama Islam pasca sertifikasi lulusan portofolio dan guru lulusan pelatihan baik secara keseluruhan, maupun dilihat dari aspek perencanaan pembelajaran, pelaksanaan pembelajaran, penilaian pembelajaran, dan pengembangan profesi, semuanya menunjukkan kinerja standar.Penelitian juga menunjukkan bahwa terdapat beberapa perbedaan antara kinerja guru sertifikasi lulusan portofolio dan lulusan pelatihan.Rekomendasi yang diajukan adalah hendaknya pelaksanaan program sertifikasi yang sudah dijalankan semaksimal mungkin harus dipertahankan dan harus ditingkatkanlagi lebih matang.
\end{abstract}

Kata Kunci: Kinerja Guru, Sertifikasi, Kompetensi.

\section{Latar Belakang}

Sertifikasi guru adalah proses pemberian sertifikasi pendidik kepada guru yang telah memenuhi persyaratan sertifikasi guru bertujuan untuk menentukan kelayakan guru dalam melaksanakan tugas sebagai pendidikan profesional, meningkatkan proses dan hasil pembelajaran, meningkatkan kesejahteraan guru, dan meningkatkan martabat guru dalam rangka mewujudkan pendidik nasional yang bermutu.

Dasar utama pelaksanaan sertifikasi adalah Undang-Undang Nomor 14 Tahun 2005 tentang Guru dan Dosen (UUGD) yang disahkan tanggal 30 desember 2005. Pasal yang menyatakan adalah pasal 8: Guru wajib memiliki kualifikasi akademik kompetisi, sertifikat pendidik, sehat jasmani dan rohani, serta memiliki kemampuan untuk mewujudkan tujuan pendidik nasional. Pasal lainnya adalah "pasal 11, ayat (1) menyebutkan bahwa sertifikat pendidik sebagaimana dalam pasal 8 diberikan kepaada guru yang telah memenuhi persyaratan."

Kemudian landasan hukum lainnya adalah Undang-Undang Nomor 20 Tahun 2003 tentang sistem pendidikan nasional dan peraturan menteri pendidikan. Nasional nomor 18 Tahun 2007 tentang sertifikasi bagi guru dalam jabatan yang ditetapkan pada tanggal 4 Mei 2007.

Pendidikan merupakan usaha sadar dan terencana untuk mewujudkan suasana belajar dan proses pembelajaran agar peserta didik secara aktif mengembangkan potensi dirinya untuk memiliki kekuatan spiritual keagamaan, pengendalian diri kepribadian, kecerdasan, akhlak mulia, serta keterampilan yang diperlukan dirinya, masyarakat, Bangsa dan Negara.

Setiap individu yang diberi tugas atau kepercayaan untuk bekerja pada suatu organisasi tertentu diharapkan mampu menunjukkan kinerja yang memuaskan dan memberikan kontribusi yang maksimal terhadap pencapaian 
organisasi tersebut.Kinerja adalah tingkat keberhasilan seseorang atau kelompok orang dalam melaksanakan tugas dan tanggung jawabnya serta kemampuan untuk mencapai tujuan dan standar yang telah ditetapkan.

Kinerja dikatakan baik dan memuaskan apabila tujuan yang dicapai sesuai dengan standar yang telah ditetapkan."Kinerja kemampuan seseorang untuk melaksanakan tugasnya yang baik untuk menghasilkan hasil yang memuaskan, guna tercapainya tujuan sebuah organisasi atau kelompok dalam suatu unit kerja.Jadi, kinerja merupakan hasil kerja di mana para guru mencapai persyaratanpersyaratan pekerjaan."

Tugas utama pendidik adalah "mendidik dan mengajar" Tetapi bukan berarti guru tidak memiliki tugas lainnya selain mendidik dan mengajar. Tugas-tugas guru yang lain di antaranya tercantum dalam UU RI No. 20 tahun 2003 tentang Sistem Pendidikan Nasional pasal 39, sebagaimana di bawah ini:

Pertama tenaga kependidikan bertugas melaksanakan administrasi, pengelolaan, pengembangan, pengawasan, dan pelayanan teknis untuk menunjang proses pendidikan pada satuan pendidikan.

Kedua pendidik merupakan tenaga profesional yang bertugas merencanakan dan melaksanakan proses pembelajaran, menilai hasil pembelajaran, melakukan bimbingan, pelatihan, serta melakukan penelitian dan pengabdian kepada masyarakat, terutama bagi pendidik pada perguruan tinggi.

Pendidik yang profesional tidak akan lepas dari kemampuan pedagogiknya, karena pedagogik merupakan ilmu yang membahas tentang pendidikan, dan juga seorang guru yang profesional dalam melaksanakan tanggung jawabnya harus sesuai dengan ketentuan yang telah ditetapkan.

Tugas guru bukan hanya mengajar untuk menyampaikan, atau mentransformasikan pengetahuan kepada para anak di sekolah, melainkan guru mengemban tugas untuk mengembangkan kepribadian anak didiknya secara terpadu. Guru mengembangkan sikap mental anak, mengembangkan hati nurani anak, sehingga anak akan sensitif terhadap masalahmasalah kemanusiaan, harkat, derajat manusia, dan menghargai sesama manusia. Begitu juga guru harus mengembangkan keterampilan anak, keterampilan hidup di masyarakat sehingga mampu untuk menghadapi segala permasalahan hidupnya.
Berdasarkan uraian di atas, diketahui bahwa untuk menjadi guru dengan predikat sebagai profesional tampaknya tidaklah mudah, tidak cukup hanya dinyatakan melalui selembar kertas yang diperoleh melalui proses sertifikasi. Karena untuk mendapatkan sertifikasi guru ada dua jalan pertama melalui fortofolio yaitu menyiapkan bahan tanpa mengikuti pelatihan dan memberikan kepada pemerintah untuk dikeluarkan sertifikat menjadi guru yang professional, dan kedua melalui mengikuti pelatihan yang diadakan selama 10 hari oleh pemerintah untuk mendapat sertifikat, maka guru dituntut untuk memiliki kemampuan menyelenggarakan proses pembelajaran dan penilaian yang menyenangkan dan sesuai dengan kriteria yang berlaku dengan tujuan agar dapat mendorong peningkatan dan tumbuhnya prestasi, motivasi, dan kreatifitas pada diri siswa.

Untuk dapat menumbuhkan kualitas dan mutu pendidikan, guru tersertifikasi akan berupaya untuk mempengaruhi emosi dan minat siswa dalam proses pembelajaran. Sehingga siswa akan selalu termotivasi dan pada akhirnya akan tercipta pembelajaran yang berdaya guna. Apabila dalam sebuah pembelajaran sudah berdaya guna tentu akan mudah bagi guru tersertifikasi untuk dapat meningkatkan mutu pendidikan yang diharapkan. Namun kurangnya tenaga pendidik yang profesional, menjadi penyebab permasalahan keilmuan yang dihadapi lembaga pendidikan saat ini, umumnya mengalami kekurangan guru yang sesuai dengan kebutuhan.

Memang jumlah tenaga pendidik secara kuantitatif sudah cukup banyak, tetapi mutu dan profesional yang ditunjang dengan sertifikasi belum sesuai dengan harapan.Banyak diantaranya yang tidak berkualitas dan menyampaikan materi yang keliru sehingga mereka tidak mampu menyajikan dan menyelenggarakan pendidikan yang benar-benar berkualitas, kemudian menyangkut dengan kinerja guru dalam perencanaan, pelaksanaan, evaluasi pembelajaran, serta kinerja guru dalam disiplin tugas di sekolah masih terlihat adanya masalah.

Dalam perencanaan pembelajaran guru masih ada yang belum membuat persiapan pembelajaran sebelum mengajar, walaupun ada namun RPP yang dibuat ketika pengawas datang, ada juga guru yang telah sertifikasi takut kepada kepala madrasah dalam artian jam 8.00 mulai belajar tapi gurunya masuk jam 
8.30alasannya kepala sekolah belum datang, jadi begitu sampai kepala madrasah, guru langsung masuk kelas, masih banyak lagi hal yang fatal dilihat pada guru sertifikasi. Selain itu juga terlihat masalah yang berhubungan dengan kinerja guru dalam pelaksanaan pembelajaran. Hal ini dapat dilihat dari guru yang belum dapat mengkondusifkan keadaan kelas menjadi tenang ketika ada siswa yang melakukan keributan dikelas.

Guru dalam pelaksanaan pembelajaran juga belum menggunakan strategi pembelajaran yang bervariasi sehingga yang terjadi pembelajaran terasa membosankan bagi siswa dan kinerja yang dihasilkan guru pun belum optimal. Dalam melakukan evaluasi pembelajaran, guru hanya melakukan evaluasi pada saat akan ujian. Begitu juga dalam disiplin tugas, guru belum mengikuti peraturan yang ditetapkan di sekolah. Sehingga kinerja guru dalam disiplin tugas pun belum optimal.

Permasalahan inilah yang menjadi faktor awal merosotnya prestasi dalam dunia pendidikan di Indonesia.Dengan adanya guru yang sudah tersertifikasi diharapkan dapat menjadikan guru sebagai guru yang profesional.Sehingga permasalahan kebijakan sekolah yang tidak populis dapat dicegah.Dengan demikian, upaya pembentukan guru yang profesional di Indonesia segera menjadi kenyataan dan diharapkan tidak semua orang dapat menjadi guru dan tidak semua orang menjadikan profesi guru sebagai batu loncatan untuk memperoleh pekerjaan.

Pada kenyataanya saat ini guru yang sudah tersertifikasi belum dapat menjalankan amanahnya dengan sebenar-benarnya sebagaimana kriteria yang telah ditetapkan.Ada indikasi bahwa guru yang telah tersertifikasi tidak lagi seproduktif ketika mereka belum mendapatkan tunjangan profesi.

Madrasah A'liyah Negeri di Kabupaten Pidie merupakan salah satu lembaga pendidikan negeri yang mengembangkan program sertifikasi guru sebagai bahagian untuk merealisasikan program pemerintah dalam mengembangkan kualitas sumber daya manusia.Sebagian guru MAN di Kabupaten Pidie adalah guru-guru yang telah mengikuti program sertifikasi.

Diharapkan dengan program tersebut dapat meningkatkan kualitas sumber daya manusia dengan cara mengembangkan konsep pendidikan yang mengarah kepada kemampuan emosional, intelektual, dan spiritual sehingga output yang dihasilkan benar-benar menjadi tenaga-tenaga ahli dalam berbagai bidang. Realita yang terjadi sertifikasi guru belum memberikan dampak yang signifikan, kebanyakan dari peserta didik belum terlihat pengembangan sikap, kecerdasan berpikir yang signifikan, para guru juga belum mampu memperlihatkan pendidikan yang bersifat positif.

Hal yang di atas merupakan asumsi awal permasalahan yang terjadi bahwa program Sertifikasi guru belum memberikan kontribusi yang lebih besar dalam usaha pengembangan mutu pendidikan dan peningkatan kualitas sumber daya manusia khususnya di MAN di Kabupaten Pidie.

\section{Rumusan Masalah}

Untuk memperoleh gambaran yang jelas tentang permasalahan di atas maka yang menjadi pokok permasalahan dalam pembahasan ini adalah sebagai berikut:

1. Bagaimana tingkat kinerja guru sertifikasi PAI yang lulus melalui fortofolio di Madrasah Aliyah Kabupaten Pidie ?

2. Bagaimana tingkat kinerja guru sertifikasi PAI yang lulus mengikuti pelatihan di Madrasah Aliyah di Kabupaten Pidie?

3. Apa perbedaan dan persamaan kinerja guru sertifikasi PAI lulus fortofolio dengan guru sertifikasi PAI lulus mengikuti pelatihan?

\section{Tujuan Penelitian}

Setiap usaha penyusun karya ilmiah mempunyai tujuan yang hendak dicapai.Sesuai dengan permasalahan diatas. Adapun tujuan penelitian dalam penulisan ini adalah sebagi berikut:

1. Untuk mengetahui tingkat kinerja guru sertifikasi PAI yang lulus melalui fortofolio di Madrasah Aliyah Kabupaten Pidie.

2. Untuk mengetahui tingkat kinerja guru sertifikasi PAI yang lulus mengikuti pelatihan di Madrasah Aliyah di Kabupaten Pidie.

3. Untuk mengetahui perbedaan dan persamaan kinerja guru sertifikasi PAI lulus fortofolio dengan guru sertifikasi PAI lulus mengikuti pelatihan

\section{Pengertian Kompetensi Profesional Guru PAI}

Guru daribahasa Sanskerta: yang berarti guru, tetapi arti secara harfiahnya adalah "berat"yaitu "seorang pengajar suatu ilmu. 
Dalam bahasa Indonesia, guru umumnya merujuk pendidik profesional dengan tugas utama mendidik, mengajar, membimbing, mengarahkan, melatih, menilai, dan mengevaluasi peserta didik."

Guru adalah "terciptanya serangkaian tingkah laku yang saling berkaitan yang dilakukan dalam situasi tertentu serta berhubungan dengan kamajuan perubahan tingkah laku dan perkembangan siswa yang menjadi tujuannya." Oleh karena itu guru merupakan unsur aparatur Negara dan abdi Negara, karena guru mutlak perlu mengetahui kebijaksanaan-kebijaksanaan pemerintah dalam bidang pendidikan, sehingga dapat melaksanakan ketentuan-ketentuan yang merupakan kebijaksanaan tersebut.

Kebijaksanaan pemerintah berupa patuh terhadap ketentuan yang berlaku dalam pendidikan kemudian juga mendidik dan membimbing siswa supaya siswa siswa adanya sustu perubahan terhadap pendidikan, perubahan itu berupa tingkah laku siswa, kemampuan siswa dalam ilmu pengetahuan, mengetahuia agama, dan lain sebagainya.

Profesional yaitu seorang guru, yang ahli dalam bidang keilmuan yang dikuasainya dituntut bukan hanya sekedar mampu mentransfer keilmuan kedalam diri anak didik, tetapi juga mampu mengembangkan potensi yang ada dalam diri poserta didik.Maka, bentuk pembelajaran kongkret dan penilaian secara komprehensif diperlukan untuk bisa melihat siswa dari berbagai perspektif. Guru profesional adalah "orang yang memiliki kemampuan dan keahlian khusus dalam bidang keguruan sehingga ia mampu melakukan tugas dan fungsinya sebagai guru dengan kemampuan yang maksimal."

Profesionalisme guru adalah suatu tingkat penampilan seseorang dalam melaksanakan pekerjaan sebagai guru yang didukung dengan keterampilan dan kode etik. Eksistensi seorang guru adalah sebagai pendidik profesional di sekolah, dalam hal ini guru sebagai uswatun hasanah, jabatan administratif, dan petugas kemasyarakatan.

Persiapan pembelajaran menjadi sesuatu yang wajib dikerjakan, dan pelaksanaan aplikasi dalam kelas berpijak kepada persiapan yang telah dibuat dengan menyesuaikan terhadap kondisi setempat atau kelas yang berbeda.Kepedulian untuk mengembangkan kemampuan afektif, emosional, sosial dan spiritual siswa, sesuatu yang vital untuk bisa melihat kelebihan atau keungulan yang terdapat dalam diri anak.Peserta didik diberi kesempatan untuk mengembangkan diri dan menemukan aktualisasi sehingga tumbuh rasa percaya diri.

Seorang guru PAI sebagai pendidik yang profesional mempunyai citra yang baik di masyarakat apabila dapat menunjukkan kepada masyarakat bahwa ia layak menjadi panutan atau teladan masyarakat sekelilingnya. Masyarakat terutama menilai guru yang profesional pada tingkah lakunya sehari-hari, apa patut diteladankan atau tidak, kemudian bagaiamana guru dalam meningkatkan pelayanan kepada siswa dana masyarakat, meningkatkan pengetahannya, memberi arahan dan dorongan kepada anak didiknya dan bagaimana guru berpakaian dan berbicara serta cara bergaul baik dengan siswa, teman-temannya serta anggota masyarakat, ini adalah menjadi perhatian masyarakat luas.

\section{Metode Penelitian}

Penelitian ini menggunakan metode deskriptif dengan pendekatan kualitatif, melalui metode deskriptif peneliti meneliti secara menyeluruh terhadap gejala yang bisa terjadi di lokasi penelitian sesuai dengan fokus permasalahan.Hal ini sebagaimana dijelaskan oleh Sujana bahwa penelitian deskriptif adalah "penelitian yang berusaha mendeskripsikan suatu gejala, peristiwa, kejadian yang terjadi saat sekarang dimana peneliti berusahamendeskripsikan peristiwa dan kejadian yang timbul di lapangan untuk kemudian digambarkan sebagaimana mestinya."

Penelitian kualitatif pada hakikatnya adalah "mengamati orang dalam lingkungan hidupnya, berinteraksi dengan mereka, berusaha memahami bahasa dan tafsiran mereka tentang dunia sekitarnya." Disamping itu penelitian kualitatif memiliki sejumlah karakteristik dan ciri-ciri tertentu melekat, seperti yang diungkapkan Nasution menyebutkan bahwa ciriciri lain dari metode penelitian kualitatif adalah:

1. Sumber data ialah situasi yang wajar atau natural setting

2. Peneliti sebagai instrument peneliti

3. Sangat deskriptif

4. Mementingkan proses atau produk

5. Memberikan makna dibelakang kelakuan atau perbuatan sehingga dapat memahami masalah atau situasi

6. Mengutamakan data langsung atau first hand

7. Triangulasi 
8. Menonjolkan rincian konstektual

9. Subjek yang diteliti dipandang berkedudukan sama dengan peneliti

10. Partisipasi tanpa mengganggu

11. Analisis sejak awal penelitian

12. Desain penelitian tampil dalam proses penelitian.

Berdasarkan penjelasan tersebut di atas maka penelitian ini berfungsi sebagai instrument penelitian dalam me profesional ningkatkan mutu pendidikan dan kinerja guru sertifikasi sebagai guru profesional oleh karena pengumpulan data dan informasi dilakukan langsung dengan subjek di lapangan yang dilaksanakan pada MAN di Kabupaten Pidie.

\section{Populasi dan Teknik Sampling}

Populasi adalah "Keseluruhan dari unitunit yang ada dan menjadi objek penelitian.Oleh karena itu penetapan objek merupakan salah satu hal yang sangat penting dalam suatu penelitian, yang tujuannya mengambil kesimpulan dari objek tersebut". Adapun yang menjadi populasi dalam penelitian ini adalah seluruh guru sertifikasi PAI yang ada pada Madrasah Aliyah di Kabupaten Pidie tahun 2014/2015, yang menjadi objek dalam penelitian ini adalah guru PAI yang telah tersertifikasi di kabupaten pidie sebanyak 8 MAN.

Untuk memperoleh keterangan tentang populasi ini penulis mungkin mengamati seluruh populasi. Mengingat dana dan waktu yang sangat terbatas, dan juga pengamatan seluruh populasi tidak praktis dan efisien. Hal ini senada dengan pendapat yang dikemukakan oleh Amudi Pasaribu bahwa: "Kita melakukan pengambilan sampel adalah karena tidak mengamati seluruh anggota populasi itu, karena pengambilan seluruh populasi tidak efisien." Oleh karena itu maka penulis mengambil sampel yang menjadi responden dalam penelitian ini sebagai berikut:

Table. 1

Populasi Guru PAI MAN Kabupaten Pidi

\begin{tabular}{|c|c|c|c|c|c|c|c|}
\hline to & $\underset{\text { Nathass:alt }}{\text { Nawd }}$ & te & Jrul & 6 SamptL & FLئ: & Jull & Yo Saruped \\
\hline 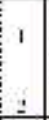 & 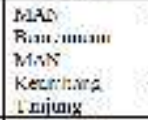 & $\begin{array}{l}1 \\
\vdots\end{array}$ & 1 & $\operatorname{sen} x$ & i & 3 & $\begin{array}{l}1 N_{i} \\
19 k_{i}\end{array}$ \\
\hline 3 & $\begin{array}{l}\text { Whis } 5 \mathrm{me} \\
\text { Wilk }\end{array}$ & 1 & 1 & inses. & $\theta$ & $B$ & $\mathrm{ri}_{i}$ \\
\hline 4 & mak latas: & $a$ & " & 9 & 1 & 1 & $102 \%$ \\
\hline ; & MAN X.1iEu & 1 & 1 & $\mathrm{IrF}_{2}$ & $\theta$ & 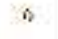 & $10 \mathrm{er}$ \\
\hline & WAL sixit & 2 & 2 & $m$ & 7 & 1 & Fesi \\
\hline
\end{tabular}

Berdasarkan tabel di atas jelas bahwa sampel yang diambil beberapa guru sertifikasi PAI lulusan pelatihan dan lulusan portofolio antara lain; Guru sertifikasi lulusan pelatihan dari MAN Beureunuen 3 orang, MAN Keumbang Tanjung 3 orang, MAN Kota Bakti 4 orang, MAN Tangse 1 orang, Man Delima, 1 orang, dan MAN Sigli 14 orang.

Sedang guru sertifikasi lulusa portofolio antara lain; 1 orang dari MAN Berueneun, 1 orang dari MAN Tangse, kemudian 2 orang dari MAN Sigli 1 setelah itu 1 orang dari MAN Kota Bakti, 2 orang dari MAN Delima, dan 1 orang dari MAN kota Bakti yang ada di Kabupaten Pidie.

\section{Teknik Pengumpulan Data}

Teknik pengumpulan data yang digunakan dalam penelitian ini adalah observasi, wawancara dan study dokumentasi. Untuk lebih cermat dalam pengumpulan data digunakan alat bantu, yaitu pedoman observasi, pedoman wawancara dan tela'ah dokumentasi, secara lebih rinci ketiga teknik pengumpulan data tersebut diuraikan sebagai berikut:

\section{a. Observasi}

Observasi merupakan teknik data dengan melakukan pengamatan dan pencatatan secara sistematik terhadap gejala dan fenomena yang ada pada objek penelitian.Adapun teknik yang digunakan adalah observasi langsung.Seperti yang diungkapkan Pabundu Tika "observasi langsung adalah pengamatan yang dilakukan terhadap objek ditempat terjadi atau berlangsungnya peristiwa, sehingga observasi berada pada objek yang diteliti”. Dalam hal ini peneliti mengadakan pengamatan langsung untuk memperoleh data yang akurat.

\section{b. Wawancara}

Wawancara adalah proses memperoleh data yang digunakan, serangkaian tanya jawab secara tatap muka, antara peneliti dan responden untuk mendapatkan informasi yang diperlukan. Adapun teknik yang digunakan adalah wawancara terstruktur dan tidak terstruktur.

\section{c. Dokumentasi}

Dokumentasi berasal dari kata dokumen, yang berarti barang tertulis. Menurut Nasution, "dokumen dapat memberikan latar belakang yang luas mengenai pokok penelitian dan dapat dijadikan triangulasiuntuk mengecek kesesuaian data. Dokumen dapat dipandang sebagai 
informasi yang dapat membantu dalam menganalisis dan menginterprestasi data." Teknik penelitian ini digunakan ketika ada data yang bersumber dari tulisan seperti dokumen tabel, dokumen tentang keadaan guru di Madrasah, dokumen keadaan siswa, dokumen fasilitas Madrasah dan dokumen mengenai sarana dan prasarana di madrasah.Teknik ini sangat penting dalam mengumpulkan data dalam sebuah dokumen yang terkait dengan lembaga tersebut. Kemudian dokumen yang akan diteliti dalam penelitian ini juga menyangkut dengan sertifikasi guru misalnya dokumen tentang perencanaan pembelajaran.

\section{Analisa Data}

Penelitian merupakan kegiatan yang terencana untuk mencari jawaban yang obyektif atas permasalahan manusia melalui prosedur ilmiah. Untuk itu didalam suatu penelitian dibutuhkan suatu proses analisis data yang berguna untuk menganalisis data-data yang telah terkumpul. Data yang sudah terkumpul namun belum dianalisis merupakan data mentah. Dalam kegiatan penelitian, data mentah akan memberi arti bila dianalisis dan ditafsirkan. Sehingga analisis data memegang peranan penting dalam penelitian.

Teknik analisis data merupakan suatu kegiatan yang membutuhkan kemampuan dan pemahaman tertentu untuk dapat menyelesaikannya. Analisis telah dimulai sejak merumuskan dan menjelaskan masalah, sebelum terjun kelapangan, dan berlangsung terus menerus sampai penulisan hasil penelitian.

Analisis data kualitatif sesungguhnya sudah dimulai saat peneliti mulai mengumpulkan data, dengan cara memilah mana data yang sesungguhnya penting atau tidak. Ukuran penting dan tidaknya mengacu pada kontribusi data tersebut pada upaya menjawab fokus penelitian.Di dalam penelitian lapangan (field research) bisa saja terjadi karena memperoleh data yang sangat menarik, peneliti mengubah fokus penelitian ini bisa dilakukan karena perjalanan penelitian kualitatif bersifat siklus.Sehingga fokus yang sudah didesain sejak awal bisa berubah di tengah jalan karena peneliti menemukan data yang sangat penting, yang sebelumnya tidak terbayangkan. Lewat data itu akan diperoleh informasi yang lebih bermakna. Untuk bisa menentukan kebermaknaan data atau informasi ini diperlukan pengertian mendalam, kecerdikan, kreativitas, kepekaan konseptual, dan pengalaman peneliti.
Maka dapat dipahami bahwa analisis data dimana kegiatan yang berkenaan dengan mengumpulkan data dan mengungkapkannya menjadi sebuah kalimat dan menginterprestasikan.Semua sumber data yang telah terkumpul dari hasil observasi, dokumentasi, dan wawancara kemudian dianalisis dengan begitu cermat berdasarkan data yang telah peneliti dapatkan. Penulis dalam menganalisis data tersebut ada beberapa model dilakukan antara lain:

1. Analisis Domain

Analisis domain pada hakikatnya adalah upaya peneliti untuk memperoleh gambaran umum tentang data untuk menjawab fokus penelitian. Caranya ialah dengan membaca naskah data secara umum dan menyeluruh untuk memperoleh domain atau ranah apa saja yang ada di dalam data tersebut. Pada tahap ini peneliti belum perlu membaca dan memahami data secara rinci dan detail karena targetnya hanya untuk memperoleh domain atau ranah. Hasil analisis ini masih berupa pengetahuan tingkat "permukaan" tentang berbagai ranah konseptual. Dari hasil pembacaan itu diperoleh hal-hal penting dari kata, frase atau bahkan kalimat untuk dibuat catatan pinggir.

2. Analisis Taksonomi.

Taksonomi merupakan suatu tipe sistem klasifikasi yang berdasarkan data penelitian ilmiah mengenai hal-hal yang digolongkangolongkan dalam sistematika itu.

Pada tahap analisis taksonomi, peneliti berupaya memahami domain-domain tertentu sesuai fokus masalah atau sasaran penelitian. Masing-masing domain mulai dipahami secara mendalam, dan membaginya lagi menjadi sub-domain, dan dari sub-domain itu dirinci lagi menjadi bagianbagian yang lebih khusus lagi hingga tidak ada lagi yang tersisa, alias habis (exhausted). Pada tahap analisis ini peneliti bisa mendalami domain dan sub-domain yang penting lewat konsultasi dengan bahan-bahan pustaka untuk memperoleh pemahaman lebih dalam.

Analisis data dalam penelitian kualitatif, dilakukan pada saat pengumpulan data berlangsung dan setelah selesai pengumpulan data dalam periode tertentu. Pada saat wawancara, peneliti sudah melakukan analisis terhadap jawaban yang diwawancarai. Bila jawaban yang diwawancarai setelah dianalisis terasa belum memuaskan, maka peneliti akan melanjutkan pertanyaan lagi, sampai tahap tertentu sehingga diperoleh data yang dianggap kredibel. Aktivitas dalam analisis data kualitatif 
dilakukan secara interaktif dan berlangsung secara terus menerus sampai tuntas. Cara yang dilakukan antara lain:

a. Penulis menganalisis data pada dokumendokumen yang didapatkan pada tempat penelitian tersebut.

b. Setelah data dokumen dianalisis apabila tidak mencukupi data yang akurat maka penulis menganalisis data ketika mengobservasi di lapangan.

c. Selanjutnya penulis menganalisis data hasil wawancara dengan objek penelitian untuk menguatkan data yang telah didapatkan sebelumnya.

\section{Hasil Penelitian}

Uraian di atas, ada beberapa hal yang perlu dianalisis berdasarkan rumusan masalah, yakni mengenai tingkat kinerja guru sertifikasi PAI lulusan Portofolio dan tingkat kinerja guru sertifikasi PAI lulusan pelatihan serta perbedaan dan persamaan antara keduanya.Untuk menganalisis data tersebut ada beberapa tahapan yang perlu dilakukan yaitu penggolongan, penyaringan kemudian penyimpulan dari datadata yang diterima.

Analisis dilakukan dengan cara analisis deskriptif kualitatif dengan pola pendekatan induktif. Analisis ini berdasarkan pada data-data yang telah diuraikan pada Bab IV dan menggunakan teori-teori yang telah dibahas pada Bab II. Adapun tujuan dilakukan analisis terhadap data hasil penelitian ini adalah untuk mendeskripsikan keadaan kinerja guru sertifikasi PAI lulusan portofolio dan lulusan pelatihan serta perbadaan kinerja kedua kategori tersebut di Kabupaten Pidie.

1. Analisis Tingkat Kinerja Guru Sertifikasi PAI Lulusan Portofolio pada Madrasah Aliyah di Kabupaten Pidie.

Mengenai Perangkat Pembelajaran sebagaimana yang tertera dalam IV halaman 8485 semua guru sertifikasi PAI lulusan portofolio melaksanakannya dan itu adalah kewajiban setiap guru. Hal itu sebagaimana diungkapkan oleh Moeh User Usman dan telah dikutip pada Bab II halaman 49, mengatakan ada beberapa indikator kinerja untuk dapat dilihat peran guru dalam meningkatkan kemampuan dalam proses belajar-mengajar. Indikator kinerja tersebut adalah:
a. Menguasai garis-garis besar penyelenggaraan pendidikan,
b. Menyesuaikan analisa materi pelajaran,
c. Menyusun program semester,

d. Menyusun program atau pembelajaran.

Sebagaimana data yang telah dipaparkan dalam Bab IV halaman 86 tentang menyusun program atau pembelajaran mencakup silabus dan rencana pelaksanaan pembelajaran pada madrasah aliyah oleh guru sertifikasi PAI portofolio semua guru mampu menyusun hal tersebut guna untuk kelancaran proses pembelajaran. Hal itu seperti yang dijelaskan dalam undang-undang RI No.20 tahun 2003 tentang Sistem Pendidikan Nasional pasal 39 dan telah dikutip dalam Bab II halaman 50, bahwa tugas-tugas guru yang tercantum dalam UU RI No. 20 tahun 2003 tentang Sistem Pendidikan Nasional pasal 39 bahwa pendidik merupakan tenaga profesional yang bertugas merencanakan dan melaksanakan proses pembelajaran, menilai hasil pembelajaran, melakukan bimbingan, pelatihan, serta melakukan penelitian dan pengabdian kepada masyarakat, terutama bagi pendidik pada perguruan tinggi.

Dalam memahami metode yang akan diterapkan dalam proses pembelajaran di kelas guru sertifikasi portofolio mampu mengunakan metode sesuai materi yang akan disampaikan dan metode tersebut bervariasi kutipan berdasarkan hasil wawancara pada halaman 8788 bab IV. Hal demikian sebagaimana yang diungkapkan oleh Nana Sudjana dikutip pada bab II hal 49 mengatakan seperangkat kemampuan yang harus dimiliki oleh seorang guru profesional, yaitu:

1. Menguasai bahan,

2. Mengelola program belajar mengajar,

3. Mengelola kelas,

4. Mengunakan media atau sumber belajar,

5. Menguasai landasan pendidikan,

6. Mengelola interaksi belajar-mengajar,

7. Menilai prestasi belajar-mengajar,

8. Mengenal fungsi bimbingan dan penyuluhan,

9. Mengenal dan meyelenggarakan admistrasi sekolah.

Sebagaimana yang tertera dalam bab IV halaman 88-89 yang mana guru sertifikasi dalam memahami dan menguasai bahan materi atau bahan ajar semua guru mampu mengajar mata pelajaran yang serumpun dengan PAI, tidak hanya mengajar mata pelajaran yang didapatkan sertifikat. Hal itu seperti yang dikemukakan oleh Depdiknas pada bab II halaman 50 meyatakan indikator kinerja guru, yaitu:

1. Penguasaan landasan kependidikan 
2. Penguasaan bahan pembelajaran

3. Pengelolaan proses belajar mengajar

4. Penggunaan alat pelajaran

5. Pemahaman metode penelitian untuk peningkatan pembelajaran, dan

6. Pemahaman administrasi sekolah

Mengenai bimbingan dan penyuluhan guru sertifikasi portofolio hanya membimbing siswa di sekolah saja tidak menindaklanjuti ke tempat kediaman siswa kutipan pada bab IV halaman 90-91, ini serti halnya yang diungkapakan oleh Nana Sudjana dikutip halaman 50 bab II bahwa seperangkat yang harus dimiliki oleh seorang guru professional adalah mengenal fungsi bimbingan dan penyuluhan.

Menilai hasil pembelajaran bagi siswa pada madrasah aliyah di Kabupaten Pidie semua guru portofolio menilai dengan aturan yang telah ditetapkan sebelumnya yaitu mereka menilai kogntif, afektif dan psikomotor di kutip halaman 92-93 bab IV. Menilai hasil pembelajaran siswa yang dilakukan ini sesuai dengan tugas-tugas guru yang dijelaskan dalam undang-undang RI no. 20 tahun 2003 tentang sistem pendidikan nasional pasal 39 dikutip pada bab II halaman 50 menyatakan Pendidik merupakan tenaga profesional yang bertugas merencanakan dan melaksanakan proses pembelajaran, menilai hasil pembelajaran, melakukan bimbingan, pelatihan, serta melakukan penelitian dan pengabdian kepada masyarakat, terutama bagi pendidik pada perguruan tinggi.

Pelaporan hasil belajar siswa yang dilakukan oleh guru sertifikasi lulusan portofolio pada madrasah aliyah yang ada di Kabupaten Pidie mereka terutama kepada wali kelas, kemudian ke kurikulum dan setelah itu baru diserahkan kepada wali murid atau kepada siswa.Hal ini sebagaimana diungkapkan oleh Moh. Uzer Usman yang bahwa dalam indikator kinerja, guru harus mampu membuat pelaporan hasil belajar siswa dikutip halaman 49 bab II.

Guru sertifikasi setelah mengajar semaksimal mungkin guru juga harus mampu melaksanakan perbaikan dan pengayaan kepada siswa, namu yang terjadi dilapangan bahwa guru sertifikasi PAI lulusan portofolio hanya melakukan perbaikan saja dikutip pada bab IV halaman 96. Hal itu sebagaiamana yang diungkapkan oleh Uzer Usman dikutip pada bab II halaman 49 mengatakan salah indikator dari kinerja guru sertifikasi adalah melaksanakan program perbaikan dan pengayaan.
Sebagaimana data yang telah dipaparkan dalam bab IV halaman 97-98 dalam mengikuti pelatihan sebagai profesi guru, guru sertifikasi portofolio ada sebagian yang mengikuti pendidikan berjenjang dan sebagian lagi tidak mengikuti pelatihan. Hal ini sebagaimana yang tercantum dalam UU RI No. 20 tahun 2003 tentang Sistem Pendidikan Nasional pasal 39 dikutip pada halaman 51 pada bab II bahwa pendidik merupakan tenaga profesional yang bertugas merencanakan dan melaksanakan proses pembelajaran, menilai hasil pembelajaran, melakukan bimbingan, pelatihan, serta melakukan penelitian dan pengabdian kepada masyarakat, terutama bagi pendidik pada perguruan tinggi.

Hasil penelitian yang dijelaskan pada halaman 98-99 bab IV bahwa semua guru sertifikasi portofolio mengabdi kepada masyarakat mereka selalu berkomunikasi yang baik dengan mereka dan juga hubungan mereka baik-baik saja. Sebagaimana yang dijelaskan dalam UU RI No. 20 Tahun 2003 tentang Sistem Pendidikan Nasional pasal 39 dikutip pada halaman 51 pada bab II pendidik merupakan tenaga profesional yang bertugas merencanakan dan melaksanakan proses pembelajaran, menilai hasil pembelajaran, melakukan bimbingan, pelatihan, serta melakukan penelitian dan pengabdian kepada masyarakat.

\section{Analisis Tingkat Kinerja Guru Sertifikasi PAI Lulusan Pelatihan pada Madrasah Aliyah di Kabupaten Pidie.}

Tingkat kinerja guru sertifikasi PAI lulusan pelatihan dilihat dari kerjanya yaitu dalam penyusunan program tahunan dan penyusunan program semester alhamdulilah semua guru menyusun program tersebut sesuai aturan yang berlaku, karena mereka mengatakan menyusun prota dan promes itu adalah kewajiban setiap guru dikutip pada halaman 101 bab IV. Hal demikian seperti yang diungkapakan oleh Nana Sudjana dikutip bab II halaman 49 mengemukakan seperangkat kemampuan yang harus dimiliki oleh seorang guru profesional menyusun program pembelajaran.

Menyusun program atau pembelajaran mencakup silabus dan rencana pelaksanaan pembelajaran pada madrasah aliyah oleh guru sertifikasi pendidikan agama Islam lulusan pelatihan semua guru melaksanakannya sebagaimana mestinya dikutip pada halaman 102-104 yang bahwasanya mereka mengatakan dalam pelaksanaan program pembelajaran 
mencakup silabus dan pelaksanaan pembelajaran diwajibkan bagi setiap guru sertifikasi. Hal itu seperti yang dingkapkan oleh Moh. Uzer Usman mengemukakan indikator kinerja untuk dapat dilihat peran guru dalam meningkatkan kemampuan dalam proses belajar-mengajar adalahMenyusun program atau pembelajaran.

Pada bab IV halaman 104 -106 mengenai pemahaman metode untuk meningkatkan pembelajaran di madrasah guru sertifikasi pendidikan agama islam merekan menggunakan beberapa metode seperti metode inkuiri, ceramah, diskusi, demontrasi dan hafalan. Kalo dilihat ini semua aalah metode lama aka tetapi merekan menggunakan metode ini sesuai dengan materi yang akan disampaikan kepda siswa. Hal itu seperti halnya yang diungkapkan oleh Nana Sudjana mengemukakan seperangkat kemampuan yang harus dimiliki oleh seorang guru profesional adalah mengelola program belajar mengajardan mengelola kelas dikutip halaman 49 bab II.

Berikut ini mengenai penguasaan bahan pembelajaran yang dilaksanakan oleh guru sertifikasi lulusan pelatihan walaupu mereka sertifikat yang didapatkannya adalah sertifikat khusus bidang studi lain tetapi mereka semua mampu menguasai bahan materi sesuai yang disampaikan kepada siswanya menyangkut dengan mata pelajaran agama Islam. Hal ini sebagaimana yang disampaikan oleh Nana Sudjana mengemukakan salah satu seperangkat kemampuan yang harus dimiliki oleh seorang guru profesional, yaituMenguasai bahan dikutip pada bab II halaman 49.

Mengenai bimbingan dan penyuluhan kepada siswa guru sertifikasi pendidikan agama Islam membimbing siswa sebaik mungkin buktinya bisa dilihat pada halaman 108 bab IV yang mana mereka membimbing siswanya dari sekolah sampai meninjau ke rumah siswa tersebut, dan, mereka mengontrol akhlak siswa supaya mereka menjadi anak yang pintar dan baik budi.

Hal yang demikian seperti yang disampaikan oleh Nana Sudjana yang bahwa salah satu seperangkat kemampuan yang harus dimiliki oleh seorang guru profesional, yaitu mengenal fungsi membimbing dan penyuluhan dikutip pada bab II halaman 50 .

Sebagaimana yang telah dipaparkan pada bab IV halaman 111 - 113 tentang penilaian hasil belajar siswa dilaksanakan sesuai dengan standarisasi yang bahwasanya pada penilaian hasil belajar siswa ini dilakukan ada beberapa tahap terutama menilai hari-hari, ada yang memberi tugas di rumah, ada dalam bentuk ujian ulangan, pra semester, ujian semester, ada juga yang menilai tingkah laku siswa akan tetapi penilaian tersebut tidak terlepas dari kognitif, afektif dan psikomotor.

Hal itu sebagaimana dijelaskandalam UU RI No. 20 tahun 2003 tentang Sistem Pendidikan Nasional pasal 39 dan telah dikutip dalam bab II halaman 50 bahwa pendidik merupakan tenaga profesional yang bertugas merencanakan dan melaksanakan proses pembelajaran, menilai hasil pembelajaran, melakukan bimbingan, pelatihan, serta melakukan penelitian dan pengabdian kepada masyarakat, terutama bagi pendidik pada perguruan tinggi.

Laporan hasil penilaian yang dilaksanakan oleh guru sertifikasi pendidikan agama Islam lulusan pelatihan pertama nilai tersebut dilaporkan kepada wali kelas, kemudian diserahkan kepada bidang kurikulum setelah itu diserahkan kepada wali murid atau kepada siswa.

Hal itu sebagaimana yang diungkapan oleh Moh. Uzer Usman dalam bab II halaman 49 mengemukakan beberapa indikator kinerja untuk dapat dilihat peran guru dalam meningkatkan kemampuan dalam proses belajar-mengajar yaitu Kemampuan mengevaluasi, yang meliputi evaluasi normatif, evaluasi formatif, dan laporan hasil evaluasi.

Kemudian mengenai pelaksanaan program perbaikan dan pengayaan guru setifikasi pendidikan agama Islam lulusan pelatihan, mereka melakukan perbaikan ketika siswa tidak mencukupi nilai standar, perbaikan ini dinamakan dengan sebutan remedial. Apabila siswa tidak mencapai $\mathrm{KKm}$ maka siswa tersebut harus mengikuti ujian kembali dengan soal yang sama diberikan kepada siswa. Hal ini seperti yang diungkap oleh Moh. Uzer Usman dalam bab II halaman 49 yang bahwasanya salah satu indikator kemampuan guru yang professional dalam kinerja adalah melaksanaan program perbaikan dan pengayaan.

Mengikuti pelatihan sebagai profesi guru oleh guru sertifikasi pendidikan agama Islam di Kabupaten Pidie, mereka mengikuti pelatihan kurikulum yang diadakan oleh Kementerian Agama ada juga yang mengikuti pelatihan diluar daerah. Hal ini sebagaimana yang tercantum dalam UU RI No. 20 tahun 2003 tentang Sistem Pendidikan Nasional pasal 39 dikutip pada halaman 51 pada bab II bahwa pendidik merupakan tenaga profesional yang bertugas 
merencanakan dan melaksanakan proses pembelajaran, menilai hasil pembelajaran, melakukan bimbingan, pelatihan, serta melakukan penelitian dan pengabdian kepada masyarakat, terutama bagi pendidik pada perguruan tinggi.

Mengabdi kepada masyarakat adalah memberikan kemampuan, pikiran dan tenaga melalui kegiatan-kegiatan yang dipersembahkan agar memberi nilai positif bagi masyarakat.Oleh karena itu guru sertifikasi pendidikan agama Islam lulusan pelatihan melakukan pengabdian kepada masyarakat yang ada disekeliling mereka dan juga mereka banyak berkecimpung dalam tokoh-tokoh masyarakat dikampung mereka sendiri seperti ada sebahagian guru yang menjadi ustaz dan ustazah.

Hal demikian seperti yang tercantum dalam UU RI No. 20 tahun 2003 tentang Sistem Pendidikan Nasional pasal 39 dalam bab II halaman 49 yatitu pendidik merupakan tenaga profesional yang bertugas merencanakan dan melaksanakan proses pembelajaran serta pelatihan serta melakukan penelitian dan pengabdian kepada masyarakat, terutama bagi pendidik pada perguruan tinggi.

\section{Analisis Perbedaan dan Persamaan \\ Kinerja Guru Sertifikasi PAI Lulus \\ Fortofolio dengan Guru Sertifikasi PAI Lulus Mengikuti Pelatihan}

Persamaan yang terlihat antara guru sertifikasi pendidikan agama Islam lulusan portofolio dengan guru sertifikasi pendidikan agama Islam adalah dalam penyusunan perangkat pembelajaran kedua kategori guru sertifikasi PAI melaksanakan melaksanakannya, ini sesuai dengan ini sesuai yang diungkapakan oleh Moh. Uzer Usman mengemukakan beberapa indikator kinerja untuk dapat dilihat peran guru dalam meningkatkan kemampuan dalam proses belajar-mengajar yaitu menyusun program semester, Menyusun program atau pembelajaran dikutip pada halaman 49 bab II.

Kemudian mengenai pembuatan rencana belajar dan mencakup silabus sama halnya yang dilakukan oleh kedua guru sertifikasi PAI. Hal itu sebagaimana yang diungkapkan oleh Moh. Uzer Usman mengemukakan indikator kinerja untuk dapat dilihat peran guru dalam meningkatkan kemampuan dalam proses belajarmengajar adalahMenyusun program atau pembelajaran kutipan bab II halaman 49.

Pada bab IV halaman 123-124 mengenai pemahaman metode untuk meningkatkan pembelajaran di Madrasah kedua guru sertifikasi pendidikan agama Islam mereka menggunakan beberapa metode seperti metode inkuiri, ceramah, diskusi, demontrasi dan hafalan. Kalau dilihat ini semua aalah metode lama aka tetapi merekan menggunakan metode ini sesuai dengan materi yang akan disampaikan kepada siswa. Hal itu seperti halnya yang diungkapkan oleh Nana Sudjana mengemukakan seperangkat kemampuan yang harus dimiliki oleh seorang guru profesional adalah Mengelola program belajar mengajardan Mengelola kelas dikutip halaman 49 bab II.

Berikut ini mengenai penguasaan bahan pembelajaran yang dilaksanakan oleh kedua guru sertifikasi karena mereka mengatakan ini adalah kewajiban bagi seorang guru. Hal ini sebagaimana yang disampaikan oleh Nana Sudjana mengemukakan salah satu seperangkat kemampuan yang harus dimiliki oleh seorang guru profesional, yaitumenguasai bahan dikutip pada bab II halaman 49.

Mengenai bimbingan dan penyuluhan kepada siswa kedua kategori guru sertifikasi pendidikan agama Islam membimbing siswa sebaik mungkin buktinya bisa dilihat pada halaman 124-125 bab IV yang mana mereka membimbing siswanya dari sekolah sampai meninjau ke rumah siswa tersebut, dan, mereka mengontrol akhlak siswa supaya mereka menjadi anak yang pintar dan baik budi. Hal yang demkian seperti yang disampaikan oleh Nana Sudjana yang bahwa salah satu seperangkat kemampuan yang harus dimiliki oleh seorang guru profesional, yaitu mengenal fungsi membimbing dan penyuluhan dikutip pada bab II halaman 50 .

Selanjutnya sebagaimana yang telah dipaparkan pada bab IV halaman 125 tentang penilaian hasil belajar siswa dilaksanakan sesuai dengan standarisasi yang bahwasanya pada penilaian hasil belajar siswa ini dilakukan ada beberapa tahap terutama menilai hari-hari, ada yang memberi tugas di rumah, ada dalam bentuk ujian ulangan, pra semester, ujian semester, ada juga yang menilai tingkah laku siswa akan tetapi penilaian tersebut tidak terlepas dari kognitif, efektif dan psikomotor.

Hal di atas dijelaskandalam UU RI No. 20 tahun 2003 tentang Sistem Pendidikan Nasional pasal 39 dan telah dikutip dalam bab II halaman 50 bahwa pendidik merupakan tenaga profesional yang bertugas merencanakan dan melaksanakan proses pembelajaran, menilai hasil pembelajaran, melakukan bimbingan, pelatihan, serta melakukan penelitian dan 
pengabdian kepada masyarakat, terutama bagi pendidik pada perguruan tinggi.

Laporan hasil penilaian yang dilaksanakan oleh kedua guru sertifikasi pendidikan agama Islam pertama nilai tersebut dilaporkan kepada wali kelas, kemudian diserahkan kepada bidang kurikulum setelah itu diserahkan kepada wali murid atau kepada siswa.Hal itu sebagaimana yang diungkapan oleh Moh. Uzer Usman dalam bab II halaman 49 mengemukakan beberapa indikator kinerja untuk dapat dilihat peran guru dalam meningkatkan kemampuan dalam proses belajar-mengajar yaitu kemampuan mengevaluasi, yang meliputi evaluasi normatif, evaluasi formatif, dan laporan hasil evaluasi.

Kemudian mengenai pelaksanaan program perbaikan dan pengayaan kedua kategori guru sertifikasi pendidikan agama Islam, mereka melakukan perbaikan ketika siswa tidak mencukupi nilai standar, perbaikan ini dinamakan dengan sebutan remedial.

Hal ini seperti yang diungkap oleh Moh. Uzer Usman dalam bab II halaman 49 yang bahwasanya salah satu indikator kemampuan guru yang profesional dalam kinerja adalah melaksanaan program perbaikan dan pengayaan. Akan tetapi kedua guru tersebut hanya saja melakukan perbaikan sedang pengayaan tidak dilihat, padahal kalau dikaji pengayaan sangat dibutuh oleh seorang siswa untuk kemantapan materi atau pelajaran yang mereka mampu.

Mengikuti pelatihan sebagai profesi guru kedua kategori guru sertifikasi pendidikan agama Islam di Kabupaten Pidie, mereka mengikuti pelatihan kurikulum yang diadakan oleh Kementerian Agama ada juga yang mengikuti pelatihan diluar daerah. Hal ini sebagaimana yang tercantum dalam UU RI No. 20 tahun 2003 tentang Sistem Pendidikan Nasional pasal 39 dikutip pada halaman 51 pada bab II bahwa pendidik merupakan tenaga profesional yang bertugas merencanakan dan melaksanakan proses pembelajaran, menilai hasil pembelajaran, melakukan bimbingan, pelatihan, serta melakukan penelitian dan pengabdian kepada masyarakat, terutama bagi pendidik pada perguruan tinggi.

Namun ada sedikit perbedaan diantara berdua, guru sertifikasi portofolio mereka mengikuti hanya mengikuti pelatihan dan seminar saja sedangkan guru sertifikasi lulusan pelatihan selain mereka mengikuti seminar dan pelatihan mereka juga melanjutkan pendidikan kejenjang berikutnya.
Mengabdi kepada masyarakat adalah memberikan kemampuan, pikiran dan tenaga melalui kegiatan-kegiatan yang dipersembahkan agar memberi nilai positif bagi masyarakat oleh karena itu kedua guru sertifikasi pendidikan agama Islam melakukan pengabdian kepada masyarakat yang ada disekeliling meraka dan juga mereka banyak berkecimpung dalam tokohtokoh masyarakat dikampung mereka sendiri seperti ada sebahagian guru yang menjadi ustaz dan ustazah.

Hal demikian seperti yang tercantum dalam UU RI No. 20 tahun 2003 tentang Sistem Pendidikan Nasional pasal 39 dalam bab II halaman 49 yatitu pendidik merupakan tenaga profesional yang bertugas merencanakan dan melaksanakan proses pembeljaran serta peltihan serta melakukan penelitian dan pengabdian kepada masyarakat, terutama bagi pendidik pada perguruan tinggi.

\section{DAFTAR PUSTAKA}

Amudi Pasaribu, Pengantar Statistik, (Jakarta: Ghalia Indonesia, 1981)

Hamalik Oemar, Pendidikan Guru Berdasarkan Pendekatan Kompetens, (Jakarta: Bumi Aksara2002)

Henry Simamora, Manajemen Sunber Daya Manusia, (Jakarta: STIE YKPN, 1995)

Heri Jauhari Muchtar, Fikih Pendidikan, (Bandung: Remaja Rosdakarya, 2005)

Moh Pabunda Tika, Metodelogi Riset Bisnis,( Jakarta: Bumi Aksara, 2006)

Moh. Uzer Usman, Menjadi Guru Profesional.( Bandung : Remaja Rosdakarya 2001)

Muhammad Ali Saifuddin, Dasar Hukum Pelaksanaan Sertifikasi, Blogspot (2010), http://www.si.html, diakses 8 juni 2014

Nana Sujana, Dasar-Dasar Proses Belajar Mengajar, ( Bandung: Rosdakarys, 1999)

Nasution, S. Metode Penelitian Naturalistic, ( Bandung: Tarsita, 1998) 
Noeng Muhajir, Metodelogi Penelitian Kualitatif. Edisi III (Yogyakarta: Rake Sarasin, 1998)

Salim dan Syahrum, Metodologi Penelitian Kualitatif, (Bandung; Citapustaka Media, 2010)

Samana, Profesionalisme Keguruan, (Yogyakarta: Kanisius, 1994)

Sugiyono, Memahami Penelitian Kualitatif, (Bandung: Perbit Alfabeta, 2010)

Sugiyono, Metode Penelitian Kombinasi. Bandung: Alfabeta, 2011)

Suharsini Arikunto, Prosedur Penelitian, (Jakarta: Rineka Cipta, 1993)

Wrightman dalam Moh Unzer Usman, Menjadi Guru Profesional, (Bandung: PT Remaja Rosda Karya, 2006),

Yunus Abu Bakar,Syarifan Nurjan, Profesi Keguruan, (Surabaya: AprintA, 2009)

Zaim Elmubarok, Membumikan Pendidikan Nilai, Cet. 2, (Bandung: Alfabeta, 2009) 